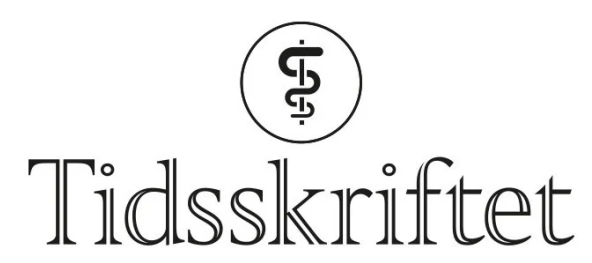

DEN NORSKE LEGEFORENING

\title{
Lege artis i sosiale medier
}

ESSAY

JAN-HENRIK OPSAHL

janhenrik@outlook.com

Jan-Henrik Opsahl er medlem av Rådet for legeetikk, spesialist i radiologi og medisinsk kommunikasjonsansvarlig i Sanofi.

Forfatteren har fylt ut ICMJE-skjemaet og oppgir ingen interessekonflikter.

\section{Er romslighet, forståelse ogydmykhet mangelvare på sosiale medier? Nettet er med på å forme hvem vi er, men vi som leger bør også bidra til å forme nettsamfunnene vi er en del} av.

Sosiale medier brukes av flere hundre millioner mennesker hver dag og har blitt en naturlig integrert del av livene til mange. Digitale sosiale nettverk har åpnet og krympet verden på en måte vi aldri har sett maken til og gitt oss et mulighetsrom uten sidestykke for profesjonell og privat kontakt med en stor gruppe mennesker, uhindret av avstand og tidsforsinkelser. Mangfoldet i den offentlige debatten har blomstret, og ethvert menneske med computer og internettilgang kan potensielt nå ut til en hel verden på relativt kort tid med sitt budskap.

Også legestanden har omfavnet den digitale æraen, og omfanget av digital undervisning, apper, digitale fora og nettverksmuligheter er raskt økende. Der vi tidligere var prisgitt uoversiktlige og støvete oppslagsverk - som regel i en hylle på et kontor langt unna - har vi nå verdens akkumulerte medisinske kunnskap liggende i frakkelommen, bare et par tastetrykk unna. Faglige råd og diskusjoner er ikke lenger begrenset til morgenmøtet og småprat over brødmaten i lunsjen, men kan like nå foregå hvor som helst-med kollegaer på den andre siden av kloden.

Mulighetene til tross er vi fortsatt nybegynnere når det kommer til forståelsen av hva disse mediene gjør med oss og hvordan formen på interaksjonene våre endres i digitale flater. Mens vi har hatt årtusener på å kultivere vår omgangsform og samtale ansikt til ansikt, har vi bare noen tiårs erfaring med digital kommunikasjon. Det sies at pennen er mektigere enn sverdet. Det kan tenkes at vi med tastatur og internett har byttet ut dette sverdet med et automatgevær. Er vi egentlig i stand til å håndtere kommunikasjon via et chatfelt, eller har vi fătt i hendene noe vi ikke helt overskuer effektene av?

\section{Hvorfor er vi i det hele tatt på sosiale medier?}


Mennesket er en sosial art, og selv når vi ikke tar pandemiens isolasjonseffekter med i beregningen, har vi et stort behov for sosial interaksjon. Bekreftelse, tilhørighet, selvhevdelse og meningsbrytning er bare noen av de sosiale behovene vi til dels kan få dekket gjennom digitale flater. Det er vist flere positive effekter av deltakelse i digitale sosiale nettverk: Tenåringer som får positive tilbakemeldinger på sin profil og sine innlegg, får en liten økning i selvtillit og opplevd velvære (1). Man har også sett at mennesker med lav livstilfredshet kan ha positive sosiale effekter av digitale sosiale nettverk (2) $)$. På den annen side har flere studier knyttet bruk av sosiale medier til økt forekomst av engstelse og depresjon, og effektene av sosiale medier på vår psykiske helse er fortsatt omdiskutert (3).

\section{Debattmiljøet på nett}

Egne erfaringer som både deltaker og tilskuer i en rekke ulike digitale fora gir inntrykk av at meningsutvekslinger og debatter lettere tilspisses og eskaleres her enn hva som er tilfelle når mennesker møtes fysisk. Temaenes relative viktighet synes også å være tilnærmet irrelevante. Steile fronter og harde personangrep kommer like gjerne i et vineller hageplanteforum som i en debatt om internasjonal politikk eller religion. Bakgrunn og utdannelse synes heller ikke å være av nevneverdig betydning, og leger og jurister i fri dressur i kommentarfeltene står på ingen måte tilbake for andre yrkesgrupper hva angår støtende utsagn og generelt usmakelig opptreden.

\section{«Mens vi har hatt årtusener på å kultivere vår omgangsform og samtale ansikt til ansikt, har vi bare noen tiårs erfaring med digital kommunikasjon»}

Rådet for legeetikk har behandlet flere klager på legers uttalelser og fremtreden i både nettaviser og sosiale medier. Lukkede nettfora for leger har vært arena for opphetede debatter hvor moderatorene har hatt en tidvis svært utfordrende oppgave med å holde diskusjonene på et saklig plan. Utenfor disse lukkede gruppene kommer enda et moment i spill: Som leger vil vår tittel være uløselig knyttet til oss når vi uttaler oss offentlig. Dette er muligens et paradoks i en tid der mange unge leger har et ønske om å skille mellom sin rolle og tid som lege og privatperson. Like fullt: I det vi kaster oss ut i kommentarfeltene eller lar kronikøren i oss få fritt spillerom, vil vi fortsatt oppfattes som representanter for legestanden - og dermed har våre uttalelser og vår opptreden betydning for fler enn bare oss selv.

Når nettet gjør mulighetene for givende meningsutveksling, læring og samarbeid nærmest grenseløse - hvordan kan det ha seg at vi så lett henfaller til arroganse, polarisering, personangrep og konfliktsøken?

\section{Om algoritmer, ekkokamre og følelser}

I artikkelen «Teaching Humility in an Age of Arrogance» skriver filosofiprofessor Michael Patrick Lynch om hvordan ydmykhet må vike for arroganse i samfunnsdebatten i stadig $\emptyset$ kende grad (4.). Polariseringen og eskaleringen av debatten som vi ofte ser i sosiale medier, drives til dels av hvordan nettbaserte medieflater fungerer. Algoritmene som driver internettet, er designet slik at de ikke bare gir oss tilgang til voldsomme mengder informasjon - de sørger for at vi får mer av akkurat den informasjonen vi vil ha og sågar av den informasjonen som vi ikke selv visste vi ville ha. Med stadig større presisjon og effektivitet får vi servert annonser, nyheter, forslag til sider å følge og politiske synspunkter som først og fremst reflekterer oss selv. Dermed bidrar vi selv til å definere våre egne ekkokamre, hvor vi fôres med stadig mer av det vi allerede tror på og oppmuntres til å se på 
alle som har avvikende meninger som feilinformerte og dumme. Slike omgivelser gir fruktbar grobunn for arroganse og nedlatenhet, og det kan kreve relativt solide doser både selvrefleksjon og selvtillit for å ikke la gruppen (for)lede våre egne meninger og utsagn.

Nettdebattenes og de sosiale medienes form fremelsker korte, tilspissede utsagn med emosjonelt innhold. En studie gjort av Brady og medarbeidere (2017) viste at innlegg med moralske og emosjonelle ordvalg fikk langt større spredning i sosiale medier enn andre innlegg. I deres studie økte hvert moralske eller emosjonelle ord i innlegg på Twitter sannsynligheten for deling av tweeten med $20 \%$ (5).

I den voldsomme informasjonsstrømmen på nettet er det liten sannsynlighet for å fange oppmerksomheten til leserne med innlegg som krever mer enn få sekunders oppmerksomhet - noe som levner lite rom for refleksjon og nyanseringer. Skal du bli sett og få respons, bør du med andre ord rope høyt, holde det kort og aller helst trykke på noen følelsesknapper.

\section{"Jo mer ansiktsløs og upersonlig interaksjonen vår er,jo lettere er det å opptre lite medmenneskelig og oppmerksomt overfor motparten»}

En post som går rett i strupen på helsemyndighetenes prioriteringer eller angriper noen for deres mening om hvem som skal covid-vaksineres først, får trolig langt mer spredning og kommentarer enn et mer balansert innlegg. Hvorfor skal man bruke tid og energi på etiske vurderinger og veloverveide utspill når det likevel forsvinner og blir raskt glemt $\mathrm{i}$ strømmen av tilspissede, emosjonelle og populistiske poster?

\section{De ansiktsløse}

Møtene våre med andre mennesker på sosiale medier er i sin natur upersonlige da vi ikke har tilgang til våre samtalepartneres kroppsspråk og toneleie. Denne mangelen på umiddelbar tilbakemelding på vår opptreden kan være en stor kommunikativ utfordring, siden vi er vant til å kontinuerlig tilpasse både budskap og form på bakgrunn av responsen vi får. Jo mer ansiktsløs og upersonlig interaksjonen vår er, jo lettere er det å opptre lite medmenneskelig og oppmerksomt overfor motparten. Når vi knytter et ansikt, en historie eller en relasjon til den vi snakker med, er det både lettere og mer naturlig å opptre omtenksomt - eller i det minste respektfullt. Jo flere allmennleger kirurgen har som personlige venner, dess vanskeligere er det å skjære hele standen over én kam.

På toppen av dette har midlertidig økt selvtillit som oppstår med ekkokammereffekten, vist seg å ha negativ effekt på oppførsel og selvkontroll (므). Summen av disse effektene gir en eksplosiv SoMe-cocktail, nærmest designet for å eskalere emosjonell debatt og konflikt.

\section{Medisinske sannheter i sosiale medier}

Demokratiseringen og muligheten for rask spredning av informasjon gjør at det blir vanskeligere å vurdere hva som er sant. Det spres mye medisinsk og vitenskapelig informasjon til både helsepersonell og pasienter på nett, mens kontrollen med spredning av medisinsk feilinformasjon i stor grad hviler på den enkeltes evne til kildekritikk.

Ifølge en studie som undersøkte forskjeller i spredning av nyheter på Twitter fra 2006 til 2017, ble falske nyheter oppfattet som ferskere og ble mer delt enn sanne nyheter (7.). Nettets algoritmer gjør ikke forskjell på helseopplysningskampanjer fra Verdens helseorganisasjon, Verdens diabetesdag, anti-vaksinasjonsopprop eller alternativ medisin mot kreft. Og evalueringen av hva som er sant, overlates til oss. 
Under covid-19-pandemien har vi sett en rask akselerasjon av spredning av medisinsk informasjon via digitale flater, og debatten om de vitenskapelige sannhetene i sosiale medier har vært intens. Mange bruker sosiale medier som en viktig kilde til nyheter $(\underline{8}, 9)$, og siden de færreste av oss har en doktorgrad i epidemiologi eller kildekritikk, har det vist seg utfordrende selv for velutdannede klinikere å få tilstrekkelig grep om hva vi kan og ikke kan vite til enhver tid. I februar 2020 advarte Verdens helseorganisasjon om at den massive «infodemien» under pandemien gjorde det svært utfordrende å finne pålitelige kilder og troverdig informasjon for folk flest (므). Like fullt har både sosiale og mer tradisjonelle medier ikke manglet selvoppnevnte epidemiologer og eksperter som med stor overbevisning har hevdet at deres sannhet er den rette.

\section{Intellektuell ydmykhet}

I lys av dette kan man spørre seg om moderasjon, ydmykhet og usikkerhet overhodet har en plass i sosiale medier - og om det har kraft til å trenge gjennom blant høylytt skråsikkerhet, fordommer og utfordrende språkbruk? Kan vi stole på de som høylytt proklamerer at de eier hele sannheten, eller er sannheten noe vi finner frem til i fellesskap, gjennom nysgjerrighet, diskusjon og åpenhet for andre perspektiver?

Videre kan vi spørre oss om det dypest sett er latskap å skylde på rammene de sosiale mediene skaper for diskusjonen? Burde vi ikke være i stand til å føre sivilisert, inspirert og gjensidig respektfull samtale selv om plattformene fasiliterer noe annet?

\section{«Burde vi ikke vare $i$ stand til å føre sivilisert, inspirert og gjensidig respektfull samtale selv om plattformene fasiliterer noe annet?»}

Emily Chamlee-Wright, president for Institutt for humane studier ved George MasonUniversitetet i USA, fremhever intellektuell ydmykhet som det mest grunnleggende for en god samtale. Siden verden er et svært komplisert sted, hvor ingen kan sitte med den hele og fulle sannhet, er vårt unike utgangspunkt både verdifullt og begrensende. Vi bringer med oss en egen innsikt i kraft av hvem vi er og hvor vi kommer fra, men dette spesifikke utgangspunktet gjør også at vi ikke alene kan favne kunnskapen som ligger i de alternative perspektivene til millioner av andre mennesker. Denne begrensningen i vår egen viten om verden betyr at vi bør begi oss inn i enhver samtale eller diskusjon med en stor porsjon ydmykhet. Vi trenger andre for å fylle våre kunnskapshull, og de trenger oss (1ㅡ).

\section{Mulighetene}

Sosiale medier er et potensielt skatt kammer av fruktbar diskusjon, læring og meningsutveksling på tvers av geografiske og kulturelle skillelinjer. Dagens leger har en hel verden av klinisk erfaring, forskningsresultater, helsepolitisk mangfold og alternative perspektiver tilgjengelig ved fingertuppene til enhver tid. Det er imidlertid til syvende og sist opp til oss hvordan vi vil benytte mulighetsrommet i disse nye arenaene.

Det er skrevet en rekke råd og retningslinjer om god debattkultur, blant annet av Arne

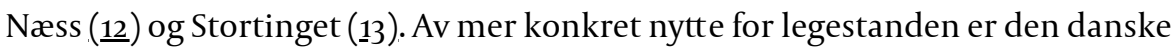
Lægeforeningens «Gode råd til læger i sociale medier» (14.) (ramme 1).

\section{Ramme 1 Gode råd til leger på sosiale medier}

Husk at du stadig er lege på sosiale medier

Oppretthold en profesjonell grense overfor dine pasienter

Husk din taushetsplikt - også når du søker legefaglig sparring på sosiale medier 
Hold en god tone og kommuniser med respekt

Vær oppmerksom på opphavsrett og samtykke ved deling av bilder

Vær varsom med markedsføring og reklame

Kjenn reglene for sletting av personopplysninger (GDPR)

Vi kan trolig ikke forvente at alle har samme syn på hva som er saklig og konstruktiv meningsutveksling på nett. Det er heller ingen farbar vei å dekke til reell uenighet og meningsmotsetninger i forsøket på å få en mer "dannet» debatt, og vi kan ikke moderere vekk alt som bryter med mer eller mindre aksepterte normer. Like fullt vil jeg hevde at de fleste meninger og motsetninger vil kunne uttrykkes på en respektfull måte. Et smått utopisk ønske ville være at de som leste denne teksten, klarte å ta inn over seg to ting før de postet sitt neste innlegg:

1. Alle (ja, absolutt alle) er mer enn det du ser.

2. Alle innehar kunnskap og erfaring som du ikke har.

Det skal nemlig godt gjøres å behandle andre respektløst med disse erkjennelsene fremst i pannelappen. Den positive bivirkningen av å møte andre med respekt er at oddsen for å bli lyttet til og møtt med samme form øker betraktelig. Med litt flaks kan vi sågar risikere å lære noe av hverandre.

\section{LITTERATUR}

1. Valkenburg PM, Peter J, Schouten AP. Friend networking sites and their relationship to adolescents' well-being and social self-esteem. Cyberpsychol Behav 2006; 9: 584-90. [PubMed][CrossRef]

2. Ellison NB, Steinfield C, Lampe C. The benefits of Facebook "friends:" Social capital and college students' use of online social network sites. J Comput Mediat Commun 2007; 12: 1143-68. [CrossRef]

3. Karim F, Oyewande AA, Abdalla LF et al. Social media use and its connection to mental health: A systematic review. Cureus 2020; 12: e8627. [PubMed][CrossRef]

4. Lynch MP. Teaching humility in an age of arrogance. The Chronicle of Higher Education 5.6.2017. https://www.chronicle.com/article/teaching-humility-in-an-age-of-arrogance/?

cid2=gen_login_refresh\&cid=gen_sign_in Lest 13.3.2021.

5. Brady WJ, Wills JA, Jost JT et al. Emotion shapes the diffusion of moralized content in social networks. Proc Natl Acad Sci U S A 2017; 114: 7313-8. [PubMed][CrossRef]

6. Wilcox K, Stephen AT. Are close friends the enemy? Online social networks, self-esteem, and selfcontrol. J Consum Res 2013; 40: 90-103. [CrossRef]

7. Vosoughi S, Roy D, Aral S. The spread of true and false news online. Science 2018;359:1146-51. [PubMed][CrossRef]

8. Shearer E, Mitchell A. News Use Across Social Media Platforms in 2020. Pew Research Center 12.1.2021. https://www.pewresearch.org/journalism/2021/o1/12/news-use-across-social-media-platformsin-2020/ Lest 28.8.2021.

9. Barn og medier i 2020. Delrapport 9.2020. Fredrikstad: Medietilsynet, 2020. https://www.medietilsynet.no/globalassets/publikasjoner/barn-og-medierundersokelser/2020/200930-delrapport-9-nyhetsvaner-barn-og-medier-2020.pdf Lest 28.8.2021.

10. World Health Organization. Munich Security Conference. https://www.who.int/directorgeneral/speeches/detail/munich-security-conference Lest 15.5.2021.

11. Chamlee-Wright E. Become an intellectual explorer: Master the art of conversation.

BigThink/Institute for Humane studies. https://bigthink.com/institute-for-humane-studies/masterconversation Lest 13.3.2021.

12. Wikipedia. Arne Næss. https://no.wikipedia.org/w/index.php? title=Arne_N\%C3\%A6ss\&oldid=20861125 Lest 24.4.2021.

13. Stortinget. \#Siifra. Hvordan delta i samfunnsdebatten.

https://www.stortinget.no/globalassets/siifra/siifra-brosjyre.pdf Lest 24.4.2021. 
14. Den danske Legeforening. Gode råd til læger på sociale medier. https://www.laeger.dk/gode-raadtil-laeger-paa-sociale-medier Lest 30.5.2021.

Publisert: 9. desember 2021. Tidsskr Nor Legeforen. DOI: 10.4045/tidsskr.21.0617

(C) Tidsskrift for Den norske legeforening 2023. Lastet ned fra tidsskriftet.no 26. april 2023. 